\title{
The Influence of Self Regulated and Traditional Learning Model on the Development of Students' Cognitive Process and Sport Enjoyment in Basketball Learning Process
}

\author{
Dian Budiana ${ }^{1}$ \\ ${ }^{1}$ Faculty of Physical Education and Health, Universitas Pendidikan Indonesia, Bandung, Indonesia \\ Correspondence: Dian Budiana, Faculty of Physical Education and Health, Universitas Pendidikan Indonesia \\ Bandung, Jl. Dr. Setiabudhi No. 229, Bandung 40154, Jawa Barat, Indonesia. E-mail: a_diabudiana@yahoo.com
}

Received: February 12, 2014

Accepted: February 20, 2014 Online Published: February 28, 2014

doi:10.5539/ass.v10n5p123

URL: http://dx.doi.org/10.5539/ass.v10n5p123

\begin{abstract}
One of the critical issues in physical education is creating a fun physical education which can develop students' cognition without ignoring the mastery of basic technique through the implementation of a learning model. To overcome the critical issue, an experiment using self regulation and traditional learning models have been applied to 60 junior high school students using randomized pretest-posttest control group design. The instruments used are questionnaire of cognition process development and sport enjoyment of which the validity and reliability have been tested. Based on the data analysis, results showed that there is an influence between the learning model and the development of cognition and sport enjoyment in basketball game learning; however, self regulation learning model gives more significant influence compared to that of traditional learning model.

This model is recommended to be used by physical education teachers in junior high school. This model can be an alternative of innovation to the learning process of physical education because it is proven to significantly influence students' cognitive development and sport enjoyment in basketball learning process.
\end{abstract}

Keywords: self regulated learning, cognitive process, sports enjoyment

\section{Background}

Physical education as the education of and through movement activities (Pangrazi \& Dauer, 1992) is the integrative part of education in general intended to develop the aspects of physical fitness, movement skill, critical and analytical thinking skill, social skill, comprehension, emotional stability, moral conduct, healthy life aspect and the recognition of healthy environment through physical activities, sport and chosen health planned systematically to achieve the National Objectives of Education (Peraturan Pemerintah Nomor 19 Tahun 2005 tentang Standar Nasional Pendidikan Jasmani). The definition which is relatively the same as proposed by Pangrazy and Dauer (Suherman, 2009) states: Physical education is a part of general educational program that contributes, primarily through movement experiences, to the total growth and development of all children. Physical education is defined as education of and through movement, and must be conducted in a manner that merit this meaning.

The objective of physical education generally is to develop all aspects of human, comprising on the aspects of cognitive, affective and psychomotor through intended and chosen physical movement with systematic methodology to develop the quality of people as a whole. To achieve that learning objective, physical education teachers should have comprehensive horizon in implementing any learning model, because the implementation of proper learning model is very essential in order to make students more autonomous, responsible and highly motivated in joining any activity in the learning process.

In its implementation, the learning process of physical education should involve all students to take part actively to get the meaningfulness from the material being studied. The great number of active and meaningful participation can enhance student cognitive process. In this context, the cognitive process is defined as student's thought which gives influence to the study including self confidence, perception, motivation and use of strategy (Witirock, in Solmon \& Lee, 1997).

One of the integral components of motivation is sports enjoyment (Scanlan et al., in Hashim et al., 2008). Sports 
enjoyment is the primary reason to start and maintain the involvement in sport (Weiss \& Chaumeton, in Hashim et al., 2008), and becomes the main predictor from the sport commitment (Carpenter \& Coleman, 1998; Scanlan et al., 1993 in Hashim et al., 2008). Sports enjoyment is the positive affective response in the process of physical education that can reflect the common senses like being cheerful, having fun and interesting. The study on sports enjoyment is very important in understanding the participation pattern in the learning process of physical education, because it can be identified consistently as the integral factor to start and maintain the involvement in the learning process of physical education (Weiss \& Petlichkoff, in Hashim et al., 2008). Sports enjoyment as the integral component of motivation can be improved through the model of attractive learning process of physical education, and according to Petlichkoff (in Hashim et al., 2008), the lack of feeling in sports enjoyment has been identified as the cause of the decrease in participation in sports and youth program in the United States.

Currently there are several articles dealing with the model of learning process which is hoped to be able to improve the cognitive skill and also the students' enjoyment in their study, without neglecting the development of their psychomotor skills, since the principles of the model assist the students to discipline themselves in every learning process. One of the model is known as Self Regulated Learning which is use in this context.

\section{Problem Statement}

The problem statement of this research is dealing with the influence of the self regulated and traditional learning model on the development of students' cognitive process and enjoyment in basketball game learning process. The research questions for this study are as follows:

1) Does the self regulated learning model and the traditional model has significant influence on the development of cognitive process and sport enjoyment in basketball learning process?

2) Does the self regulated learning model give higher and more significant influence than traditional model on the cognitive development in basketball learning process?

3) Does the self regulated learning model give higher and more significant influence than traditional model on the sport enjoyment in basketball learning process?

\section{Methodology}

To determine the influence of self regulated learning on the development of cognitive process and sport enjoyment, experimental method using two different groups were utilized. The first group uses self regulated learning model while the second uses the usual method commonly done by the teacher which in the context of this research is known as the traditional learning model. The research design is the randomized pretest-posttest control group design (Fraenkel \& Wallen, 2002), while the data analyses technique used is multi-variant analysis (Ghozali, 2009). The research was conducted on junior high schools students between the ages of 13 to 14 years old. This age group was specifically chosen because it is the ultimate time of affectionate to the physical or sport activities, with indoor soccer and basketball as the most preferable one. The sampling technique is simple random sampling. Data were collected using questionnaires. The questionnaire for cognitive process is used to measure the students' cognitive process in the learning process of basketball which comprises the aspects of self regulation, confidence, care, willingness to be involved, and strategy (Witirock, 1986), while the questionnaire for sports enjoyment is used to measure the enjoyment in basketball learning process which includes self perception, enjoyment acquired from the teachers, interaction, parents' involvement, self competence, and enjoyment derived from the physical or sport activities (Scanlan \& Lewthwaite, 1986).

\section{Result}

\subsection{Descriptive Data Statistics}

Table 1 show the result of descriptive data analysis. 
Table 1. Descriptive statistics for cognitive process and sports enjoyment using self regulation model and traditional model

\begin{tabular}{lllll}
\hline & Model of Learning & Mean & Deviation Standard & N \\
\hline Pre Test & A1 MP. Self Regulation & 75.53 & 3.608 & 30 \\
Cognitive Process & A2 MP. Traditional & 76.00 & 4.202 & 30 \\
& Total & 75.77 & 3.890 & 60 \\
Pre Test & A1 MP. Self Regulation & 71.03 & 3.306 & 30 \\
Sport Enjoyment & A2 MP. Traditional & 71.07 & 3.850 & 30 \\
& Total & 71.05 & 3.558 & 60 \\
Post Test & A1 MP. Self Regulation & 80.10 & 3.209 & 30 \\
Coginitive Process & A2 MP. Traditional & 77.83 & 3.931 & 30 \\
& Total & 78.97 & 3.737 & 60 \\
Post Test & A1 MP. Self Regulation & 77.10 & 5.622 & 30 \\
Sport Enjoyment & A2 MP. Traditional & 71.23 & 3.360 & 30 \\
& Total & 74.17 & 5.462 & 60 \\
Gain Score & A1 MP. Self Regulation & 4.57 & 2.096 & 30 \\
Cognitive Process & A2 MP. Traditional & 1.83 & 2.465 & 30 \\
& Total & 3.20 & 2.654 & 60 \\
Gain Score & A1 MP. Self Regulation & 6.07 & 4.433 & 30 \\
Sport Enjoyment & A2 MP. Traditional & 0.17 & 3.824 & 30 \\
& Total & 3.12 & 5.069 & 60 \\
\hline
\end{tabular}

To examine the hypothesis, multivariate analysis using gain score is conducted. The use of gain score is to ensure that the improvement is really based on the treatment given. Result of the multivariate analysis is shown in Table 2 .

Table 2. Multivariate test

\begin{tabular}{ccccccccc}
\hline & \multicolumn{1}{c}{ Effect } & Value & F & Hypothesis df & Error df & Sig & Partial Eta Square \\
\hline \multirow{4}{*}{ Intercept } & Pillai's Trace & .999 & $8014.515^{\mathrm{a}}$ & 6.000 & 53.000 & .000 & .999 \\
& Wilks' Lambda & .001 & $8014.515^{\mathrm{a}}$ & 6.000 & 53.000 & .000 & .999 \\
& Hotelling's Trace & 907.304 & $8014.515^{\mathrm{a}}$ & 6.000 & 53.000 & .000 & .999 \\
& Roy's Largest Root & 907.304 & $8014.515^{\mathrm{a}}$ & 6.000 & 53.000 & .000 & .999 \\
\multirow{5}{*}{ Model of Learning } & Pillai's Trace & .699 & $20.492^{\mathrm{a}}$ & 6.000 & 53.000 & .000 & .699 \\
& Wilks' Lambda &. $\mathbf{3 0 1}$ & $\mathbf{2 0 . 4 9 2}^{\mathbf{a}}$ & $\mathbf{6 . 0 0 0}$ & $\mathbf{5 3 . 0 0 0}$ & $\mathbf{. 0 0 0}$ & $\mathbf{. 6 9 9}$ \\
& Hotelling's Trace & 2.320 & $20.492^{\mathrm{a}}$ & 6.000 & 53.000 & .000 & .699 \\
& Roy's Largest Root & 2.320 & $20.492^{\mathrm{a}}$ & 6.000 & 53.000 & .000 & .699 \\
\hline
\end{tabular}

The Wilks' Lambda test in the multivariate analysis gives the $F$ value of 20.492 and is significant at $p=0.000$. This shows that the model of the learning process has very significant influence on the development of cognitive process and sports enjoyment in basketball learning process. Thus, the hypothesis which states that the learning 
model gives significant influence on the development of cognitive process and sport enjoyment is accepted. While the variability of the development of cognitive process variable and sport enjoyment can be explained by learning model variable is $69.9 \%$ as shown by the Partial Eta Squared.

Table 3. Pairwise comparison

95\% Confidence Interval

\begin{tabular}{llcccc}
\multicolumn{1}{c}{ Dependent Variable } & \multicolumn{1}{c}{ A } & Mean & Std. Error & Lower Bound & Upper Bound \\
\hline Coginitive Process & A1 MP. Self Regulation & 4.567 & .418 & 3.731 & 5.403 \\
& A2 MP. Traditional & 1.833 & .418 & .997 & 2.669 \\
Sport Enjoyment & A1 MP. Self Regulation & 6.067 & .756 & 4.554 & 7.580 \\
& A2 MP. Traditional & .167 & .756 & -1.346 & 1.680 \\
\hline
\end{tabular}

Table 4. Pairwise comparison

\begin{tabular}{|c|c|c|c|c|c|c|c|}
\hline \multirow{3}{*}{$\begin{array}{l}\text { Dependent } \\
\text { Variable }\end{array}$} & \multirow[b]{3}{*}{ (I) $\mathrm{A}$} & \multirow[b]{3}{*}{ (J) A } & \multirow{3}{*}{$\begin{array}{l}\text { Mean } \\
\text { Difference (I-J) }\end{array}$} & \multirow{3}{*}{$\begin{array}{l}\text { Std. } \\
\text { Error }\end{array}$} & \multicolumn{3}{|c|}{$\begin{array}{l}\text { 95\% Confidence Interval } \\
\text { for Difference }\end{array}$} \\
\hline & & & & & & Lower & \\
\hline & & & & & Sig..$^{a}$ & Bound & Upper Bound \\
\hline \multirow{4}{*}{$\begin{array}{l}\text { Coginitive } \\
\text { Process }\end{array}$} & A1 MP. Self & A2 MP. & $2.733^{*}$ & .591 & .000 & 1.551 & 3.916 \\
\hline & Regulation & Traditional & & & & & \\
\hline & A2 MP. & A1 MP. Self & $-2.733^{*}$ & .591 & .000 & -3.916 & -1.551 \\
\hline & Traditional & Regulation & & & & & \\
\hline \multirow{4}{*}{$\begin{array}{l}\text { Sport } \\
\text { Enjoyment }\end{array}$} & A1 MP. Self & A2 MP. & $5.900^{*}$ & 1.069 & .000 & 3.760 & 8.040 \\
\hline & Regulation & Traditional & & & & & \\
\hline & A2 MP. & A1 MP. Self & $-5.900^{*}$ & 1.069 & .000 & -8.040 & -3.760 \\
\hline & Traditional & Regulation & & & & & \\
\hline
\end{tabular}

Based on the result of pairwise comparison analysis shown in Table 3 and 4, it can be concluded that:

1) There is a significant difference on the development of cognitive process between students who uses the self regulated learning model (mean $=4.567)$ with the traditional model $($ mean $=1.833)$. The cognitive process using self regulated learning model is better than using the traditional model. Thus, the hypothesis which states that the self regulated learning model gives higher and significant influence than the traditional model on the cognitive process in basketball learning process is accepted.

2) There is a significant difference in sports enjoyment between the students who were taught using self regulated model $($ mean $=6.067)$ with the traditional model $($ mean $=0.167)$. Sports enjoyment which is taught using the self regulated model is higher than the traditional method. Thus, the hypothesis which states that self regulated model gives higher and significant influence than the traditional model on the sport enjoyment in basketball learning process is accepted.

\section{Discussion}

Based on the result of data analysis, it was found that the learning models of both self regulated and traditional method gives significant influence to the development of cognitive process and sport enjoyment in basketball game. However, there is a significant difference of cognitive process development between students who were taught using self regulated model and those who were taught using the traditional model. The cognitive process taught using self regulated model is higher than using traditional method, because the self regulated model is a theoretical framework to students comprehend activities during the learning process which is built on the social 
cognitive theory (Pintrich et al., 1990). This shows that the students taught by self regulated model will have autonomy in their study therefore that they can manage their conduct, motivation and cognition while at the same time are able to identify the objective of the lesson. Schunk (in Ao man-Chih, 2006) states that the learning process of self regulated method involves self-instruction, attribution, achievement motivation and assignment value, and cognitive activity (meta-cognitive, self-monitoring and self-evaluation) so that the students become more autonomous in the learning process of physical education.

Since the self regulated learning model includes activities that involves cognitive, motivation and behavior skills, the model can be the means of achieving the goals in physical education. As a learning model, implementation of is supported by 3 strategies, namely learning strategy, management strategy and the knowledge about the learning. Kermarrec et al., (2008) states that learning strategy, management strategy and knowledge of learning are the strategic components in the implementation of self regulated learning model in physical education.

Data analysis shows a difference in significant sport enjoyment between the students who are taught using self regulated model and the traditional one. Sport enjoyment using self regulated model is higher than those who are taught using traditional model. This is similar with research finding of Nahas et al. (Ao man Chih, 2006) who studied the determinant factors of physical activities on senior high school and university students majoring in physical education. Their research showed that the behavior modification focuses on implementation of self regulated skill and improvement in social support to increase physical activity participation, while cognitive behaviorism does not focus only on strategy of self regulation, but also emphasizes motivational confidenceh to be actively involved in every learning activity. The involvement of sport enjoyment aspect in self regulated model deals with the students' psychological condition to enhance conduct that aims at achieving the learning activity. Psychological condition is influential to the students conduct represented in the manner to achieve the learning activity. The learning activity which is supported by cheerful psychological environment will give positive effect to the behavior during the process of self regulated learning in physical education class such as carrying out the assignment, managing time and motivation, searching for the assistance, decreasing peer interaction, adjusting the difficulty level, repeating and training (Kermarrec et al., 2004).

Regulating effort deals with students' effort to take control over their learning endeavor. Effort regulation is also known as resource management (Pintrich, 2000; Hidayat et al., 2008). Effort regulation is an mportant aspect in self regulated model which reflects the strong commitment to reach the learning goal, including the condition when students are faced to certain difficulties in their learning process. In the performance and learning activity of movement skill, effort regulation plays important role because it is not only beneficial to improve the motivation and build commitment, but also relate it with the use of other learning strategies (Pintrich, 2000; Budiana, 2010). Help seeking in self regulated learning is needed by students and is related with the behavioral component in self regulated learning (Newman, 1994, 1998; Hidayat, 2010). The aspect of help seeking is important especially when students are faced with difficulties to learn movement skill that they cannot perform, therefore, the teacher's and their peer's help will be very helpful. Zimmerman and Martinez-Pons (1990) emphasize that help seeking is one strategy in self regulated learning related with the aspect of motivation and behavior which plays an important role to improve performance and result of students' learning. Liukkonen, et al. (2007) mention the two mostly repeated aspects done by students in self regulated model which is regulating their efforts and searching for assistance (help seeking) if students find difficulty in learning in physical education.

In general, the finding in this research shows that self regulated model gives higher and significant influence to the development of cognitive process and sport enjoyment than the traditional model. These findings strengthen past empirical research which states that self regulated model endorses students to study in integrative manner between the aspects of cognitive, affective and psychomotor, while traditional learning model emphasizes more on aspect of behavior or psychomotor.

\section{Conclusion, Implication and Recommendation}

\subsection{Conclusion}

Based on the data analysis and the discussion, the following conclusion can be made:

1) Self regulated learning model and traditional learning model gives significant influence on the development of cognitive process and sport enjoyment.

2) Self regulated learning model gives higher and more significant influence on the development of cognitive process than the traditional learning method 
3) Self regulated learning model gives higher and more significant influence on the students' sport enjoyment than the traditional learning model.

\subsection{Implication}

Based on the result of this research, it can be stated in general that self regulated learning model can be an alternative learning model to be used by teachers of physical education in junior high school level. Furthermore, based on this research finding, some important implications for the realization of physical education learning process in junior high school level in its relationship with the implementation of self regulated learning model among others are: teachers should try to meet the students' needs and demands, and guide them to comprehend the characteristics of the subject being studied by identifying students' ability and promote the basic movement skill from the lowest level to the highest, in order to help students to manage the objective of their learning activity. In the first level of self regulated learning, the objective should be more focused on the process rather than on the result. This is intended to prevent students from being frustrated and set back from the learning process when they face difficulty in the first step of learning the new material. Besides that, teachers should also take into consideration individual differences and give chance to students to take part and compete, and suggest them to do observation and self scoring on the process of learning movement skill that they perform by making notes about the factors related with the learning activities they have, and assist students to revise the movement and check it during the learning process, so that students will be able to arrange their own learning material. In self regulated model, teachers should always empower their students as the models in demonstrating the newly learned movement skill and students' feed back in the learning process will enhance the use of self regulation among other students. Besides that, to increase the cognitive process development and sport enjoyment in the physical education, teachers should consider to convey the material and assignment in meaningful, relevant and interesting material for students, such as conveying the material based on the existed skill which is in line with the principle of DAP (Developmentally Appropriate Practice), give correction according to the students' need and shape the learning process in such interesting way consisted of innovative learning variation.

\subsection{Recommendation}

Based on the conclusion of the research, some recommendations are: increasing knowledge on learning models that can be used in physical education, and involvement of stake holders in the socialization process is important. It is hoped that there will be further research using some other variables from the result of physical education, for instance in elementary school level or senior high school level by taking into consideration the intervening variable like: psychomotor skill difference, environment condition, and gender. The result of this research also recommends that self regulated learning model is used by teachers of physical education in elementary and particularly in junior high school level as one of the alternative innovation in learning physical education, because it has been proved that self regulated learning model gives significant influence on the development of cognitive process and sport enjoyment. Finally, the researcher hopes that this research will come with the great benefits for all readers in general and particularly for the researcher himself and gives meaningful contribution to the development of physical education in the future.

\section{References}

Budiana, D., Hidayat, Y., \& Budiman, D. (2010). Aplikasi Pendekatan Pembelajaran Self Regulated Learning dalam Pembelajaran Pendidikan Jasmani di Sekolah Dasar. Laporan Penelitian.

Chih, M. A. (2006). The Effect of the Use of Self Regulated Learning Strategies on College Student's Performance and Satisfaction in Physical Education. A Thesis Submitted in Partial Fulfillment of The Requirements of The Degree of Doctor Education. Australian Catholic University.

Fraenkel. R. J., \& Wallen, E. N. (2002). How to Design and Evaluate Research in Education (2nd ed.). Philadelphia: Harcourt Brace College Publishers.

Ghozali, I. (2009). Model persamaan struktural. Konsep dan aplikasi dengan program Amos 16.0. Semarang: Badan Penerbit Universitas Dipenogoro.

Hashim, H., Grove, R. J., \& Whipp, P. (2008). Validating the Youth Sport Enjoyment Construct in High School Physical Education. Journal Research Quaterty for Exercise and Sport, 79(2), 183-194. http://dx.doi.org/10.1080/02701367.2008.10599482

Hidayat, Y., Budiana, D., \& Budiman, D. (2008). Aplikasi Pendekatan Pembelajaran Self Regulated Learning dalam Pembelajaran Pendidikan Jasmani di Sekolah Dasar. Laporan Penelitian.

Kermarrec, G., Todorovich, J. R., \& Fleming, D. S. (2004). An Investigation of the Self-Regulation Componens 
Student Employ in Physical Education Setting. Journal of Teaching in Physical Education, 23(2), 142.

Liukkonen, J., Auweele, Y. V., Vereijken, B., Alferman, D., \& Thedorajis, Y. (2007). Psychology for Physical Educators. Canada: Human Kinetics.

Newman, R. S. (1994). Adaptive Helf Seeking: A Strategy of Self Regulated Learning. In D. H. Schunk, \& B. J. Zimmerman (Eds.), Self-Regulation pf learning and perfor-mance: Issues and Educational Applications (pp. 283-301). Hillsdale, NJ: Erlbaum.

Newman, R. S. (1998). Student's Helf Seeking During Probling Solving: Influence of Personal and Contextual Achievement Goals. Journal of Educational Psycho-logy, 90, 644-658. http://dx.doi.org/10.1037/0022-0663.90.4.644

Pangraji, R. O., \& Dauer, V. P. (1992). Dynamic Physical Education for Elementary School Children (10th ed.). Macmillan Pubblishing Company, New York.

Peraturan Pemerintah Nomor 19. (2005). Tentang Standar Nasional Pendidikan Jasmani. Jakarta, Depdiknas

Pintrich, R. (2000). Multiple Goal, Multiple Pathways: The Role of Goal Orientations in Learning and $\begin{array}{llll}\text { Achievement. Journal of Educational Psychology, 92, 544-555. } & \text { of }\end{array}$ http://dx.doi.org/10.1037/0022-0663.92.3.544

Pintrich, R. P., \& De Groot, E. (1990). Motivation and Self-Regulated Learning Components of Classroom Academic Performance. Journal of Educational Psychology, 82(1), 33-40. http://dx.doi.org/10.1037/0022-0663.82.1.33

Suherman, A. (2009). Reviatlisasi Pengajaran dalam Pendidikan Jasmani. Penerbit: CV. Bintang Warli Artika.

Zimmerman, B. J., \& Martinez-Pons, M. (1990). Self differences in self regulated learning: Relating grade, sex, and giftedness to the self efficacy and strategy use. Journal of Educational Psychology, 82(1), 51-59. http://dx.doi.org/10.1037/0022-0663.82.1.51

\section{Copyrights}

Copyright for this article is retained by the author(s), with first publication rights granted to the journal.

This is an open-access article distributed under the terms and conditions of the Creative Commons Attribution license (http://creativecommons.org/licenses/by/3.0/). 